\title{
Towards an Empirical Definition of Graduate School Healthcare Informatics
}

\author{
Thomas Virgona, $\mathrm{PhD}$ \\ Assistant Professor Adelphi University
}

\section{Introduction}

Healthcare informatics is a relatively new field to academia. As with all new innovations, there may be some time before the Healthcare Informatics discipline has a firm foothold on a definition. Although healthcare informatics has spurred many unique degree names, all agree the field is multi-disciplinary in nature. In a new school or program, there may not be any standardized curricula or set course syllabi, which leaves considerable room for creativity and flexibility (HD Covvey, 2001). Oregon Health \& Science University has developed a program that includes to the full spectrum of courses, allowing education to be tailored to career goals and needs (Hersh, 2007). Although the field of health informatics encompasses many established disciplines, the field itself is still in a formative state that allows for teaching and curriculum development in a way that may not be possible in more established educational programs. It is difficult to talk of informatics education since the groups that need education in this field are not very homogeneous (Arie Hasman, 2000).

Graduate degree addressing healthcare informatics goes by many names;

- Bioinformatics

- Health Information Technology

- Health Management Information Systems

- Health Informatics

- Public Health Informatics

- Medical Informatics

- Consumer health informatics Jun/Jul 2013).

Regardless of the health domain, all informatics subspecialties apply the informatics pyramid;(White,

- The relationship and transformation of data.

- Information and knowledge, to making decisions and solve problems.

This pilot study was performed at add clarity to the multi-disciplined nature of Healthcare Informatics.

\section{Literature Review}

Research found Healthcare Informatics course development have included the following disciplines; business, legal, chemical informatics, bioinformatics, new media, copyright, trademark and patents (HD Covvey, 2001). The science of informatics has driven innovation in biomedical research, clinical care, and public health (CAHIIM, 2014). While each Healthcare Informatics program has specific targeted academic goals and audiences, there is overlapand some confusion related to the new field. Until recently, medical informatics focused on developing applications for health professionals - through the eyes of health professionals rather than through the eyes of patients. Today, medical informatics is "the field that concerns itself with the cognitive, information processing, and communication tasks of medical practice, education, and research". (Eysenbach, 2000)

With the diversity of approaches within health informatics, research is looking to define where appropriate relationships exist among information sciences, information technology and informatics. (Dalrymple, Jun/Jul 2013). Today, health informatics professionals contribute to: (AMIA, 2014)

- Moving basic research findings from bench to bedside;

- Evaluating interventions across communities;

- Assessing the impact of health innovations on health policy; and

- Advancing the field of informatics.

Thehealth informatics focus is changing towards usability, specifically for consumers. Currently, healthcare workers see the clinical informatics in discrete pieces (Reese, May 2012). Health informatics is not restricted to the use of computers and telecommunications but also includes the delivery of information to 
patients through other media. The computer may not always be the most effective medium for delivering information, especially in dealing with elderly or injured patients(Eysenbach, 2000). Public Health Informatics (PHI) leverages information and computer science to support public health goals and decision-making while defining the science behind the technology (White, Jun/Jul 2013). PHI utilizes a range of disciplines, including information science, engineering, law and the social sciences (Savel, 2012). Discussions are now focused on developing and evaluating methods and applications to integrate consumer needs and preferences into information management systems in clinical practice, education, and research.

Health informatics education has started in the 1960s, primarily in medical schools across the USA and Europe. By 1989 health informatics education had grown into more than 20 countries on five continents (Hovenga, 2000). In 1999, Indiana University created a new school, the School of Informatics, representing a wide range of disciplines (Hook, 2003). All health informatics programs are unique in terms or content and structure - reflecting many foundation disciplines.

The evidence suggests a poor uptake of informatics by the nursing profession (Hovenga, 2000). One contributing factor is the lack of a standardized nursing terminology. In order for the informatics goal of full interoperability across nursing information systems to be realized, this problem must be addressed (Schwirian, 2013).

The Commission on Accreditation for Health Informatics and Information Management Education (CAHIIM) is an independent accrediting organization that enforces quality Accreditation Standards for Health Informatics and Health Information Management (HIM) educational programs. (CAHIIM, 2014)An academic program in health informatics needs to include:

- Information Systems curriculum components focus on such issues as information systems analysis, design, implementation, management and leadership.

- Informatics curriculum components are concerned with the study of structure, function and transfer of information, socio-technical aspects of health computing, and human-computer interaction.

- Information Technology curriculum components focus on computer networks, database and systems administration, security, and programming.

- Nurses must be supported consistently in their use of standardized nursing terminologies;

- Cross-mappings among the various terminologies must be completed.

Clearly healthcare informatics graduate program are in their formative state. A review of the literature that describes the growth of these programs indicates the varied nature of the programs;

- multi-disciplinary

- full spectrum

- tailored

- diversity

- include curriculum components from all three facets

Despite the agreement on the growth and the multi-disciplinary nature of the discipline, there has not been an effort to define what the spectrums of courses that comprise a healthcare informatics degree.

\section{Research purpose and questions}

\section{Research Methodology}

The purpose of this pilot study was to start to define the cross-disciplinary nature of a Healthcare Informatics graduate degree. Researchers in the field agree on that the discipline includes a full spectrum of courses, but the diversity of courses remains vague. Consequently, many prospective students are confused by the goals of the degree

- What courses comprise a Healthcare Informatics graduate degree?

- What disciplinescontribute courses/curriculumto the Healthcare Informatics graduate degree programs?

\section{Methodology}

For this study, a content analysis of courses in a Healthcare Informatics graduate degree program was conducted, using a representative sample of universities. The design goal was to construct a sample frame corresponds to the population (Universities / Colleges)(Fowler, 2002).

Content analysis requires two processes: definition of the content characteristics (basic content elements) being examined and application of rules for identifying and recording these characteristics. An objective coding scheme must be applied to the courses (Berg, 2001). For this pilot study, each course was placed into an academic discipline. Four disciplines were selected for this study; Business (BUS), Healthcare (HC), Information Systems (IS) and Healthcare Informatics (HCI). 
The guidelines for identifying a discipline for each category were;

\begin{tabular}{|c|c|}
\hline Discipline Category & Course content \\
\hline Business & $\begin{array}{l}\text { Administration } \\
\text { Business of Informatics in Healthcare } \\
\text { Communication Skills } \\
\text { Ethics \& Legal Issues in Health Informatics } \\
\text { Leadership Development } \\
\text { Legal and Social Issues in Health Informatics } \\
\text { Management Theory } \\
\text { Negotiations \& Conflict Resolution } \\
\text { Operations } \\
\text { Organizational Behavior } \\
\text { Organizational Communication } \\
\text { Organizational Management and } \\
\text { Total Quality Management }\end{array}$ \\
\hline Healthcare & $\begin{array}{l}\text { Bioinformatics } \\
\text { Epidemiology } \\
\text { Genomics and } \\
\text { Health Care Data } \\
\text { Health Education } \\
\text { Health Systems Lab } \\
\text { Nursing Research } \\
\text { The American Health Care System }\end{array}$ \\
\hline Healthcare Informatics & $\begin{array}{l}\text { Biostatistics and Decision Analysis } \\
\text { Capstone HIT Research Project } \\
\text { Capstone Project } \\
\text { Foundations of Health Information Management } \\
\text { Health Care Informatics } \\
\text { Health Care Informatics Internship } \\
\text { Health Informatics Capstone Experience } \\
\text { Human Interactions, Integration and Interoperability } \\
\text { Introduction to HealthCare Informatics } \\
\text { Medical Terminology } \\
\text { Medical Terminology } \\
\text { Principles of Health Informatics } \\
\text { Research and Evaluation } \\
\text { Seminar in Biomedical and Health Information Sciences } \\
\text { Seminar on Current Issues in Healthcare Informatics and Enterprise Management } \\
\text { Social \& Org. Issues in Health Informatics } \\
\text { Strategic Inquiry in HIS } \\
\text { Survey of Health Information Management } \\
\text { Topics in Health Informatics }\end{array}$ \\
\hline
\end{tabular}




\begin{tabular}{|c|c|}
\hline Discipline Category & Course content \\
\hline Information Systems & $\begin{array}{l}\text { Application of Health Care Info. Sys. } \\
\text { Artificial Intelligence } \\
\text { Computational Models of Decision Making } \\
\text { Computer Applications } \\
\text { Computer Networks } \\
\text { Creation and Application of Medical Knowledge } \\
\text { Data Architecture and Modeling } \\
\text { Data Communications } \\
\text { Data Security } \\
\text { Data Security } \\
\text { Design for Usability in Health Care } \\
\text { Electronic Networking and Information Services } \\
\text { Emerging Technologies in Healthcare } \\
\text { Health Care I.T. Administration } \\
\text { Health Care Information Security } \\
\text { Health Care Project Management } \\
\text { Health Info. Sys. Analysis \& Design } \\
\text { Health Informatics Applications } \\
\text { Health Information Technology Procurement } \\
\text { Healthcare Information Technology } \\
\text { Information Sources \& Services } \\
\text { Information Systems Analysis } \\
\text { Infrastructure for Electronic Business } \\
\text { Introduction to Computer Security } \\
\text { IT Vendor Management } \\
\text { Knowledge Management in Healthcare Organizations } \\
\text { Knowledge Representation } \\
\text { Managed Care \& Integrated Health Networks } \\
\text { Management Information Systems } \\
\text { Management of Health Care Comm. Sys. } \\
\text { MIS Concepts \& Languages } \\
\text { Mobile Health Informatics } \\
\text { Natural Language Processing } \\
\text { Object-Oriented \& Visual Paradigms } \\
\text { Project Management } \\
\text { System Analysis and Design } \\
\text { Topics in Computer Science } \\
\text { Work Flow Design, and Change Management }\end{array}$ \\
\hline
\end{tabular}

One design issue is how well the sample frame corresponds to the population a researcher wants to describe. (Fowler 1993). Is this a true picture? By using a reprehensive sample, the goal was that the information derived from the sample and the conclusions reflected the same conditions that exist in University settings as a whole (Glebocki, 1984). Specifically excluded from the sample was "for-profit universities", defined as colleges that are owned and operated by businesses and are ultimately accountable by law for the returns they produce for shareholders. (Senate Committe on Health, Education, Labor and Pensions, 2014). The sample selected for this pilot study (January 2014) will be one university that is;
- Online
- Traditional
- Public
- Private
- Large School
- Small School

The following working definitions for this study were used;

\begin{tabular}{|l|l|}
\hline Term & Definition \\
\hline Large university & $\begin{array}{l}\text { Large Universities have more than 15,000 students (Anonymous, 2014). } \\
\text { Although a more detailed criteria, credit hours is not readily available - "Large university" means a } \\
\text { university that produces more than 150,000 student credit hours per academic year } \\
\text { (State of New Mexico, 2014). }\end{array}$ \\
\hline Small university & $\begin{array}{l}\text { Small Universities have fewer than 5,000 students(Anonymous, 2014). } \\
\text { Although a more detailed criteria, credit hours are not readily available - "Small university" means a } \\
\text { university that produces 150,000 or fewer student credit hours per academic year. (State of New } \\
\text { Mexico, 2014) }\end{array}$ \\
\hline Private University & $\begin{array}{l}\text { The term "private" simply means that the university's funding comes from tuition, investments and } \\
\text { private donors, not from taxpayers. (Grove, 2014) }\end{array}$ \\
\hline
\end{tabular}




\begin{tabular}{|l|l|}
\hline Term & Definition \\
\hline Public University & $\begin{array}{l}\text { The term "public" indicates that the university's funding comes partly from state taxpayers. (Grove, } \\
2014)\end{array}$ \\
\hline Online & $100 \%$ of the courses are offered online \\
\hline
\end{tabular}

\section{Research Findings}

For this pilot study, six universities were selected as a representative sample of Healthcare Informatics graduate programs. The six were;

\begin{tabular}{|c|c|c|c|}
\hline & Institution & Rationale for Selection & Website \\
\hline Online & $\begin{array}{l}\text { University of } \\
\text { Illinois at } \\
\text { Chicago }\end{array}$ & $\begin{array}{l}\text { The continuum of our online health } \\
\text { informatics degree programs enables } \\
\text { professionals from various backgrounds to } \\
\text { acquire the skills necessary to transition into } \\
\text { a wide variety of health informatics roles. }\end{array}$ & $\begin{array}{l}\text { http://healthinformatics.uic.edu/ } \\
\text { http://healthinformaticsdegree.ui } \\
\text { c.edu/masters-health-informatics/ }\end{array}$ \\
\hline $\begin{array}{l}\text { Traditi } \\
\text { onal }\end{array}$ & $\begin{array}{l}\text { Northeastern } \\
\text { University }\end{array}$ & $\begin{array}{l}\text { Both online or on campus } \\
\text { http://www.ccs.neu.edu/graduate/degree- } \\
\text { programs/m-s-in-health- } \\
\text { informatics/program-overview/ }\end{array}$ & $\begin{array}{l}\text { http://www.healthinformatics.ne } \\
\text { u.edu/overview/index.html }\end{array}$ \\
\hline Public & $\begin{array}{l}\text { University of } \\
\text { Wisconsin- } \\
\text { Milwaukee }\end{array}$ & Public University & $\begin{array}{l}\text { http://www4.uwm.edu/chs/acade } \\
\text { mics/hia/his/ms-hci/ }\end{array}$ \\
\hline Private & $\begin{array}{l}\text { Adelphi } \\
\text { University }\end{array}$ & $\begin{array}{l}\text { From its beginnings as a private preparatory } \\
\text { school in Brooklyn, Adelphi has steadily } \\
\text { pursued its mission of providing quality } \\
\text { education while serving the needs of an ever- } \\
\text { expanding community. Even in the most } \\
\text { challenging times, Adelphi has expanded into } \\
\text { new academic disciplines. }\end{array}$ & $\begin{array}{l}\text { http://nursing.adelphi.edu/acade } \\
\text { mics/healthcare-informatics/ }\end{array}$ \\
\hline $\begin{array}{l}\text { Large } \\
\text { School }\end{array}$ & $\begin{array}{l}\text { University of } \\
\text { Central } \\
\text { Florida }\end{array}$ & $\begin{array}{l}\text { The University of Central Florida and its } 12 \\
\text { colleges provide opportunities to } 60,000 \\
\text { students from all } 50 \text { states and } 140 \text { countries. }\end{array}$ & $\begin{array}{l}\text { http://graduatecatalog.ucf.edu/pr } \\
\text { ograms/Program.aspx?ID=5852 }\end{array}$ \\
\hline $\begin{array}{l}\text { Small } \\
\text { School }\end{array}$ & $\begin{array}{l}\text { New England } \\
\text { College }\end{array}$ & Student enrollment 3,536 & $\begin{array}{l}\text { http://www.nec.edu/pdf-files- } \\
\text { 1/grad-prof-studies/msm/health- } \\
\text { informatics/?searchterm=informa } \\
\text { tics }\end{array}$ \\
\hline
\end{tabular}

Once the six academic institutions were selected, the website for each Graduate Program for Healthcare Informatics was visited. All of the courses (required and / or electives) were documented and recorded. The courses included in each program were; 


\begin{tabular}{|c|c|}
\hline Institution & Courses \\
\hline $\begin{array}{l}\text { University of Illinois at } \\
\text { Chicago }\end{array}$ & $\begin{array}{l}\text { BHIS } 406 \text { Medical Terminology } \\
\text { HIM } 486 \text { Foundations of Health Information Management } \\
\text { Course Work } \\
\text { BHIS } 437 \text { Health Care Data } \\
\text { BHIS } 499 \text { Info. Sources in Biomedical \& HIS } \\
\text { BHIS } 503 \text { Communication Skills in Health Informatics } \\
\text { BHIS } 505 \text { Ethics \& Legal Issues in Health Informatics } \\
\text { BHIS } 510 \text { Health Care Information Systems } \\
\text { BHIS } 511 \text { Application of Health Care Info. Sys. } \\
\text { BHIS } 515 \text { Management of Health Care Comm. Sys. } \\
\text { BHIS } 520 \text { Health Info. Sys. Analysis \& Design } \\
\text { BHIS } 525 \text { Social \& Org. Issues in Health Informatics } \\
\text { BHIS } 537 \text { Health Care IT Vendor Management } \\
\text { BHIS } 593 \text { Health Informatics Capstone Experience } \\
\text { Additional Core - Course Only Track } \\
\text { BHIS } 530 \text { Topics in Health Informatics } \\
\text { Additional Core - Research Track } \\
\text { BHIS } 500 \text { Strategic Inquiry in BHIS } \\
\text { BHIS } 595 \text { Seminar in Biomedical and Health Information Sciences } \\
\text { BHIS } 597 \text { Research in Biomedical and Health Information Sciences } \\
\text { BHIS } 598 \text { Research in Biomedical and Health Information Sciences } \\
\text { Electives - Other Courses Offered } \\
\text { BHIS } 543 \text { Health Care Project Management } \\
\text { BHIS } 527 \text { Knowledge Management in Healthcare Organizations } \\
\text { BHIS } 508 \text { Q-Methodology Research Methods } \\
\text { BHIS } 509 \text { Informatics for the Clinical Investigator } \\
\text { BHIS } 517 \text { Health Care Information Security } \\
\text { BHIS } 528 \text { Consumer Health Informatics } \\
\text { BHIS } 538 \text { Health Care I.T. Administration } \\
\text { BHIS } 546 \text { Leadership Development in Health Informatics } \\
\text { BHIS } 580 \text { Practicum in Biomedical and Health Information Sciences } \\
\text { BHIS } 596 \text { Independent Study } \\
\text { BHIS } 522 \text { Mobile Health Informatics }\end{array}$ \\
\hline Northeastern University & $\begin{array}{l}\text { Required Courses: } 2 \text { Courses } \\
\text { HINF } 5101 \text { Introduction to Health Informatics and Health Information Systems } \\
\text { HINF } 5105 \text { The American Health Care System } \\
\text { Health Informatics: Choose } 2 \text { courses } \\
\text { HINF } 6225 \text { Health Systems Lab } \\
\text { HINF } 6202 \text { The Business of Health Care Informatics } \\
\text { HINF } 6205 \text { Creation and Application of Medical Knowledge } \\
\text { Technical: Choose } 2 \text { Courses } \\
\text { HINF } 6220 \text { Database Design, Access, Modeling, and Security } \\
\text { HINF } 6230 \text { Strategic Topics in Programming for Health Professionals } \\
\text { HINF } 5102 \text { Data Management in Health Care } \\
\text { HINF } 6355 \text { Key Standards in Health Informatics Systems } \\
\text { Business Management: Choose } 2 \text { Courses } \\
\text { HINF } 6201 \text { Organizational Behavior, Work Flow Design, and Change Management } \\
\text { HINF } 6215 \text { Project Management } \\
\text { HINF } 6335 \text { Management Issues in Healthcare Information Technology } \\
\text { Elective Courses (choose } 2 \text { courses) } \\
\text { HINF } 6345 \text { Design for Usability in Health Care } \\
\text { HINF } 6330 \text { Emerging Technologies in Healthcare } \\
\text { HINF } 6340 \text { Introduction to Genomics and Bioinformatics } \\
\text { HINF } 6325 \text { Legal and Social Issues in Health Informatics } \\
\text { HINF } 6350 \text { Public Health Surveillance and Informatics } \\
\text { Capstone (one course) } \\
\text { HINF } 7701 \text { Health Informatics Capstone Project }\end{array}$ \\
\hline
\end{tabular}




\begin{tabular}{|c|c|}
\hline Institution & Courses \\
\hline $\begin{array}{l}\text { University of } \\
\text { Wisconsin-Milwaukee }\end{array}$ & 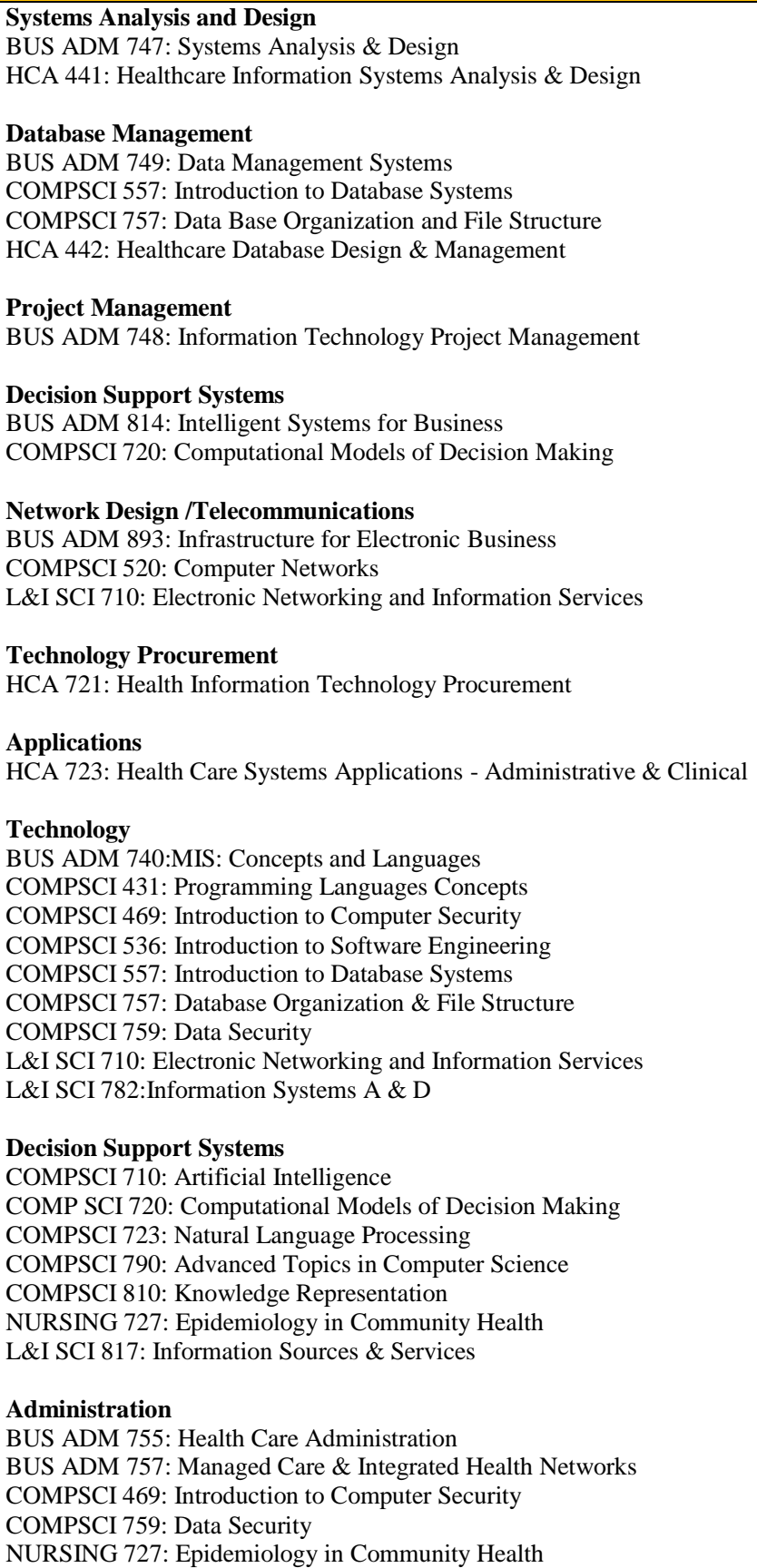 \\
\hline Adelphi University & $\begin{array}{l}\text { HED } 602 \text { Research and Technology in Health Education } \\
\text { HIT } 502 \text { Introduction to U.S. Health Care Organization } \\
\text { HIT } 601 \text { HIT Human Interactions, Integration and Interoperability } \\
\text { HIT } 603 \text { Decision Support Systems in HIT } \\
\text { HIT } 650 \text { Field Experience in HIT } \\
\text { HIT } 701 \text { Capstone HIT Research Project } \\
\text { MGT } 561 \text { Management Theory and Organizational Behavior } \\
\text { NUR } 606 \text { Quantitative Analysis for Nursing Research } \\
\text { DSC } 501 \text { Computer Applications } \\
\text { DSC } 573 \text { Management Information Systems } \\
\text { DSC } 574 \text { Information Systems Analysis } \\
\text { DSC } 678 \text { Best Practices, Operations, and Total Quality Management } \\
\text { OPR } 576 \text { Data Communications }\end{array}$ \\
\hline
\end{tabular}




\begin{tabular}{|c|c|}
\hline Institution & Courses \\
\hline $\begin{array}{l}\text { University of Central } \\
\text { Florida }\end{array}$ & $\begin{array}{l}\text { Health Care Informatics } \\
\text { HCA 700: Introduction to HealthCare Informatics } \\
\text { Programming } \\
\text { BUS ADM 740: MIS Concepts \& Languages } \\
\text { BUS ADM 813: Object-Oriented \& Visual Paradigms } \\
\text { Prerequisites } \\
\text { HIM } 6007 \text { Survey of Health Information Management } \\
\text { HIM } 6267 \text { Foundation of Health Services Administration } \\
\text { HIM 6477 Medical Terminology for Informatics Professionals } \\
\text { Required Courses } \\
\text { HIM 5118C Health Care Informatics and Information Technology } \\
\text { HIM 6119C Biostatistics and Decision Analysis } \\
\text { HIM 6122C System Analysis and Design } \\
\text { HIM 6123C Health Informatics Applications-Administrative, Financial and Clinical Project Management } \\
\text { HIM 6124C Health Care Data Architecture and Modeling } \\
\text { HIM 6125 Health Care Informatics Capstone } \\
\text { HIM 6217C Health Care Database Management } \\
\text { HIM 6464C Epidemiology, Analytics and Quality Management } \\
\text { HIM 6935 Seminar on Current Issues in Healthcare Informatics and Enterprise Management } \\
\text { HIM 6947 Health Care Informatics Internship }\end{array}$ \\
\hline New England College & $\begin{array}{l}\text { Principles of Health Informatics } \\
\text { Research and Evaluation } \\
\text { Healthcare Technology and Systems } \\
\text { Knowledge Management in Healthcare } \\
\text { The Business of Informatics in Healthcare } \\
\text { MG } 6110 \text { Managing Projects } \\
\text { MG } 5110 \text { Organizational Management and Leadership Development } \\
\text { MG } 5410 \text { Organizational Communication, Negotiations \& Conflict Resolution } \\
\text { Capstone Project }\end{array}$ \\
\hline
\end{tabular}

The literature review of graduate programs in Healthcare Informatics shows the programs to be multidisciplinary in nature. Does a review of the specific courses in each program support that generalization?

After performing content analysis on the 120 courses from the 6 institutions, the findings do indicate Healthcare Informatics is a multi-disciplinary field. The breakdown is $64 \%$ Informations Systems courses, $32 \%$ Healthcare Informatics, $10 \%$ Business courses and 9\% Healthcare courses. The supports the statement of Healthcare Informatics as a multi-disciplinary field.

\begin{tabular}{|c|c|c|c|c|c|c|c|}
\hline Discipline & Count of Course & \multirow{2}{*}{\multicolumn{5}{|c|}{ Healthcare Informatics Courses by Discipline }} & \multirow{7}{*}{ - Total } \\
\hline BUS & 13 & \multirow{6}{*}{$\begin{array}{r}80 \\
60 \\
40 \\
20 \\
0\end{array}$} & & & & & \\
\hline $\mathrm{HC}$ & 11 & & & & & & \\
\hline $\mathrm{HCI}$ & 32 & & & & & & \\
\hline IS & 64 & & & & & & \\
\hline \multirow[t]{2}{*}{ Grand Total } & 120 & & & & & & \\
\hline & & & BUS & $\mathrm{HC}$ & $\mathrm{HCl}$ & IS & \\
\hline
\end{tabular}

A more detailed review of the data shows two anomalies. The University of Wisconsin-Milwaukee had the largest amount of Healthcare Informatics courses, the vast majority being Information Systems related. New England College has the fewest classes - nine (seven of which were 4 credit classes).

\begin{tabular}{|l|c|c|c|c|c|}
\hline University & BUS & HC & HCI & IS & Grand Total \\
\hline Adelphi University & 2 & 3 & 4 & 4 & 13 \\
\hline New England College & 3 & & 3 & 3 & 9 \\
\hline Northeastern University & 2 & 4 & 3 & 9 & 18 \\
\hline University of Central Florida & 1 & 1 & 8 & 6 & 16 \\
\hline University of Illinois at Chicago & 3 & 1 & 14 & 11 & 29 \\
\hline University of Wisconsin-Milwaukee & 2 & 2 & & 31 & 35 \\
\hline Grand Total & $\mathbf{1 3}$ & $\mathbf{1 1}$ & $\mathbf{3 2}$ & $\mathbf{6 4}$ & $\mathbf{1 2 0}$ \\
\hline
\end{tabular}




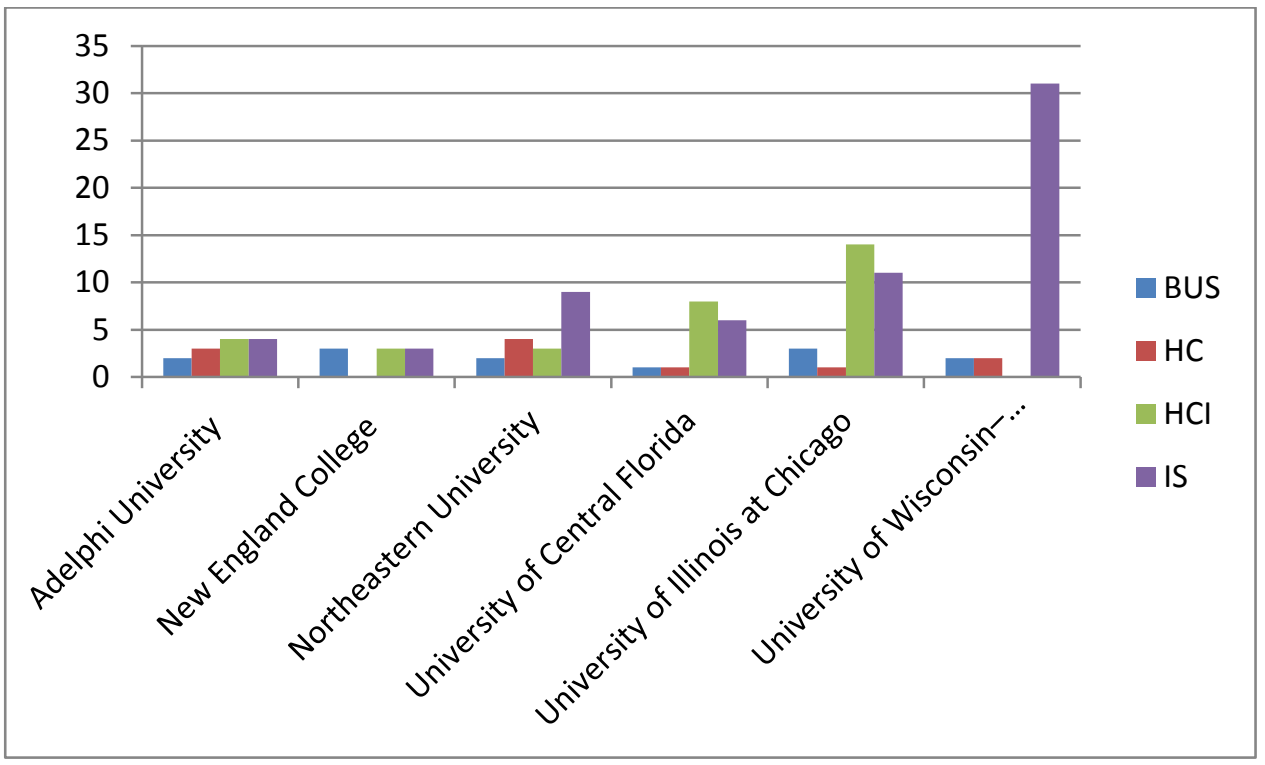

\section{Conclusions}

This pilot study to define the multi-disciplinary nature of Healthcare Informatics has provided fertile ground for future research. Future research should expand the sample size to include more institutions and also investigate if courses in other disciplines are included in Healthcare Informatics graduate programs. Although not a research question for this pilot study, there appears to be a relationship between the students enrollment in a University and the number of courses offered in the program.

\section{References}

[1]. AMIA. (2014, 01 08). About AMIA. Retrieved from About AMIA: http://www.amia.org/

[2]. Anonymous. (2014, 01 10). College Size: Small, Medium or Large? Retrieved from College 411: http://www.collegedata.com/cs/content/content_choosearticle_tmpl.jhtml?articleId=10006

[3]. Arie Hasman, R. H. (2000). Thoughts about Curricula in Health Informatics. Studies in Health Technology and Informatics, 72:2733.

[4]. Berg, B. (2001). Qualitative research methods for the social sciences (4th ed.). Boston: Allyn and Bacon.

[5]. CAHIIM. (2014, 01 08). Health Informatics Graduate Education Programs. Retrieved from Health Informatics Graduate Education Programs: http://www.cahiim.org/applyaccred_HI_grad.html

[6]. Dalrymple, P. (Jun/Jul 2013). Health Informatics: Introduction. Bulletin of the American Society for Information Science and Technology (Online), 18-19.

[7]. Eysenbach, G. (2000). Consumer health informatics. British Medical Journal, International edition, $1713-6$.

[8]. Fowler, F. (2002). Survey research methods. Thousands Oaks, CA: Sage Publisher.

[9]. Glebocki, J. (1984). In search of the wild hypothesis : an adventure in statistics for non-statisticians . Parker, CO : Anderson-Bell.

[10]. Grove, A. (2014, 01 10). Private University. Retrieved from College Admissions: http://collegeapps.about.com/od/glossaryofkeyterms/g/private-university-definition.htm

[11]. HD Covvey, D. Z. (2001). The development of model curricula for health informatics. Medinfo, 10(pt2):1009-13

[12]. Hersh, W. (2007). The full spectrum of biomedical informatics education at Oregon Health \& Science University. Methods Inf Med, 46(1):80-3.

[13]. Hook, S. A. (2003). Teaching health informatics: designing a course for a new graduate informatics program. J Med Libr Assoc, 91(4): 490-492.

[14]. Hovenga, E. (2000). Global health informatics education. Stud Health Technol Inform, 57:3-14.

[15]. Reese, S. (May 2012). Trust is a barrier to embracing informatics. Managed Healthcare Executive, 36.

[16]. Savel, T. G. (2012). The role of public health informatics in enhancing public health surveillance: CDC's Vision for Public Health Surveillance in the 21st Century. Morbidity and Mortality Weekly Report (MMWR), 20-24

[17]. Schwirian, P. M. (2013). Informatics and the Future of Nursing: Harnessing the Power of Standardized Nursing Terminology. Bulletin of the Association for Information Science and Technology, 39(5).

[18]. Senate Committe on Health, Education, Labor and Pensions. (2014, 10 01). Executive Summary. Retrieved from Executive Summary: http://www.help.senate.gov/imo/media/for_profit_report/ExecutiveSummary.pdf

[19]. State of New Mexico. (2014, 10 10). State of New Mexico Higher Education. Retrieved from Provisions for 5.7.14 NMAC apply to all: http://www.nmcpr.state.nm.us/nmac/parts/title05/05.007.0014.htm

[20]. White, M. (2013). Public Health Informatics: An Invitation to the Field. Bulletin of the Association for Information Science and Technology, 39(5), 0. Retrieved from http://www.asis.org/Bulletin/Jun-13/JunJul13 White.html\#3

[21]. White, M. (2013). Public Health Informatics: An Invitation to the Field. Bulletin of the Association for Information Science and Technology, 0-1.

[22]. White, M. (Jun/Jul 2013). Public Health Informatics: An Invitation to the Field. Bulletin of the American Society for Information Science and Technology (Online), 25-29. 